\title{
PEMBELAJARAN JIGSAW DENGAN KOMPETENSI KONSELOR PADA PROGRAM STUDI BIMBINGAN DAN KONSELING
}

\author{
Tri Mega Ralasari $\mathrm{S}^{1)}$ \\ 1) IKIP PGRI Pontianak, Pontianak, Indonesia \\ Email:mega88.mt@gmail.com
}

\begin{abstract}
Abstrak. Tujuan penelitian pembelajaran dengan metode jigsaw pada dasarnya adalah metode pembelajaran yang diarahkan kepada mahasiswa Program Studi Pendidikan Bimbingan dan Konseling dengan mendasarkan pada kompetensi guru meliputi aspek kepribadian, sosial, profesional, dan pedagogis. Namun, lebih menekankan pada standar kompetensi konselor yang menyatukan antara kompetensi akademik dan kompetensi profesional. Langkah-langkah dalam penelitian merujuk pada metode penelitian dan pengembangan berdasarkan metode jigsaw dengan modifikasi tahapan dan nilai-nilai yang pada umumnya bercirikan kerja kelompok untuk belajar dan partisipasi dalam kelompok, dengan kegiatan sebagai berikut:listening, speaking-student untuk lebih menguasai kompetensi, kerjasama setiap anggota, refleksi, dan berfikir kreatif. Dari penelitian diperoleh hasil, pembelajaran jigsaw dengan kompetensi konselor dapat disampaikan pada mahasiswa Pendidikan Program Studi Bimbingan dan Konseling dengan memperhatikan aspek (1) memahami secara mendalam konseli yang dilayani, (2) menguasai landasan dan kerangka teoretik bimbingan dan konseling.
\end{abstract}

Kata kunci: Pembelajaran; Jig Saw; Kompetensi Konselor

\section{Pendahuluan}

Belajar pada tingkatan perguruan tinggi, khususnya untuk mahasiswa kependidikan menuntut pencapaian empat kompetensi dasar seorang pendidik meliputi kompetensi sosial, kompetensi kepribadian, kompetensi profesional, dan kompetensi pedagogis. Namun demikian, masih banyak mahasiswa di perguruan tinggi, dalam hal ini mahasiswa Program Studi Bimbingan dan Konseling IKIP PGRI Pontianak yang dijadikan sebagai subyek dan lokasi penelitian belum mumpuni dalam menunjukkan kompetensi yang diharapkan tersebut. Hal ini ditunjukan dengan pemerolehan IPK dibawah rata rata 3,00 pada tiap semesternya, ketidakmampuan dalam mentransformasi hasil belajar pada mata kuliah berkelanjutan, belum memiliki keyakinan dan kepercayaan diri sebagai seorang calon pendidik untuk menyatakan pendapat, gagasan, meskipun sebatas wacana dan bukan teori, kurangnya sikap ilmiah dalam menanggapi dan menjawab pertanyaan maupun menjabarkan materi pembahasan dalam tiap mata kuliah sehingga jawaban yang disampaikan masih seputar hal hal yang umum dan belum konkrit untuk menghubungkannya dengan sisi praksis dari materi ajar.

Kompetensi atau competency berarti "Kemampuan seorang pendidik mengaplikasikan dan memanfaatkan situasi belajar mengajar dengan menggunakan prinsipprinsip dan teknik penyajian bahan pelajaran yang telah disiapkan secara matang, sehingga dapat diserap peserta didik dengan mudah". Menurut Mungin [1] istilah kompetensi digunakan dalam dua konteks yaitu: "Sebagai indikator kemampuan yang menunjukkan kepada perbuatan yang dapat diobservasi dan sebagai konsep yang mencakup aspek-aspek kognitif dan afektif dengan tahapan pelaksanaannya". Kompetensi dalam penelitian ini adalah kompetensi yang khusus diperuntukkan bagi konselor. Yaitu, suatu cara untuk mengajak, merangsang dan memberikan kesempatan pada siswanya agar ikut serta mengemukakan pendapat, belajar mengambil keputusan, bekerja dalam kelompok, membuat laporan, berdiskusi, yang semuanya ini membawa siswa pada suasana belajar aktif. Konteks tugas konselor berada dalam kawasan pelayanan yang bertujuan mengembangkan potensi dan memandirikan konseli dalam pengambilan keputusan dan pilihan untuk mewujudkan kehidupan yang produktif, sejahtera, dan peduli kemaslahatan umum.

Berdasarkan kajian penelitian dari Banun Sri Haksasi dan Heru Mugiarso [2] menyebutkan kerangka berpikir dalam bingkai budaya konselor berimplikasi pada tuntutan persyaratan yang harus dimiliki oleh seorang konselor dalam pendekatan konseling multikultural, yakni: kemampuan pemahaman terhadap konseli sangat dipengaruhi oleh variabel, latar budaya, sosial, cirri khas individu dan latar psikologis sebagai frame antara konselor dan konseli. Hal ini menandakan bahwa, kompetensi konselor multikultural menyisipkan standar kompetensi konselor secara umum yang mengarah pada kemampuan memahami secara mendalam konseli yang dilayani dan menguasai landasan dan kerangka teoretik bimbingan dan konseling. Sementara ekspektasi kinerja konselor dalam aplikasinya, sebagaimana disebutkan dalam penelitian Restu Setyoningtyas [3], menunjukkan hasil yang positif untuk menyampaikan pelayanan dan kinerja professional untuk mencapai keefektifan guru BK dalam pekerjaannya di lapangan sebagai pelaksana layanan Bimbingan dan Konseling. 
Berdasarkan pertimbangan tersebut dapat diperoleh gambaran secara fundamental tentang pentingnya kompetensi konselor untuk lebih diperhatikan dan dipertahankan demi tercapainya tujuan pembelajaran dalam proses belajar mengajar maupun pemberian layanan kepada siswa. Berkaitan dengan hal tersebut, maka metode pembelajaran yang dapat di berikan untuk meningkatkan mutu pembelajaran dalam proses belajar mengajar maupun layanan terutama dalam layanan klasikal yang diberikan oleh konselor adalah melalui pendekatan jigsaw. Teori yeng melandasi pembelajaran kooperatif jigsaw adalah teori konstruktivisme. Pada dasarnya pendekatan teori konstruktivisme dalam belajar adalah suatu pendekatan di mana siswa secara individu menemukan dan mentransformasikan informasi yang kompleks, memeriksa informasi dengan aturan yang dan merevisinya bila perlu [4].

Hasil observasi peneliti kepada beberapa dosen pengampu mata kuliah pada Program Studi Bimbingan dan Konseling. Metode yang kerap dipilih oleh dosen pengampu adalam metode ceramah dan diskusi masih belum mampu untuk mengarahkan pada komunikasi multi arah serta diskusi yang berjalan sebatas pada pemaparan materi dan direspon oleh hanya beberapa mahasiswa yang memiliki keaktifan di kelas (tidak merata) namun landasan jawaban belum cukup ilmiah sebab mahasiswa sekedar mengutip namun belum memahami penuh makna kutipan yang diambil tersebut. Maka, teknik jigsaw dipilih dan digunakan untuk menguasai kompetensi, kerjasama setiap anggota, refleksi, dan berfikir kreatif.

\section{METODE}

Metode penelitian menggunakan pendekatan penelitian dan pengembangan (research and development). Kerangka isi dan komponen model disusun berdasarkan kajian konsep kompetensi konselo yang diinternalisasikan dalam kajian konsep komponen pembelajaran jigsaw, serta kajian empiris tentang kondisi aktual pembelajaran mahasiswa pada program studi Bimbingan dan Konseling IKIP-PGRI Pontianak.

Metode ini dimaksudkan untuk melaksanakan uji coba lapangan dalam rangka mengetahui keefektifan model yang dikembangkan. Metode eksperimen ini digunakan untuk mengetahui efektifitas implementasi pembelajaran jigsaw. Variabel bebas yang dimanipulasi dalam penelitian ini yaitu pembelajaran jigsaw, dengan variabel terikatnya adalah kompetensi konselor.

Kegiatan yang dilakukan pada sepuluh tahapan proses penelitian dan pengembangan sebgaimana yang disarankan oleh Borg dan Gall di modifikasi oleh peneliti dan dijelaskan sebagai berikut: (1) penelitian dan pengumpulan informasi, yaitu meliputi pengkajian literatur berupa kajian penelitian yang relevan tentang metode jigsaw maupun metode belajar yang kerap digunakan oleh dosen berupa metode ceramah dan metode diskusi konvensional dengan menggunakan angket pendapat penggunaan metode ajar oleh dosen dan tipe belajar mahasiswa serta wawancara terhadap beberapa subjek secara random. (2) Pengamatan lapangan berkenaan dengan kemampuan mahasiswa dalam memahami dan mengolah informasi untuk menerima perkuliahan serta mentransformasikan hasil belajar dan proses pembelajaran yang dilakukan dengan memperhatikan beberapa aspek berkenaan dengan kompetensi konselor, yaitu (a) memahami secara mendalam konseli yang dilayani, dengan data penunjang berupa data diri mahasiswa; rekap hasil evaluasi belajar mahasiswa dari semester 1-2, serta pola perilaku belajar selama proses pembelajaran di dalam kelas maupun di luar kelas, (b) menguasai landasan dan kerangka teoretik bimbingan dan konseling dengan memberikan kuis bagi mahasiswa untuk mengetahui pemahaman awal terhadap materi yang hendak diukur dalam mata kuliah dasar-dasar bimbingan dan konseling. (3) Penyiapan laporan untuk setiap pertemuan yang dilakukan selama 1 semester pada kelas sampel; (4) perencanaan, yaitu meliputi perumusan tujuan pendidikan, menentukan urutan pembelajaran, dan uji kelayakan berskala kecil; (5) pengembangan bentuk produk awal, yaitu meliputi penyiapan materi pembelajaran, buku pegangan, dan alat evaluasi. Pengembangan produk atau model dalam penelitian ini didasarkan pada temuan penelitian yang dilaksanakan dengan menerapkan metode studi kasus, dan teori-teori yang mendasari pembelajaran jigsaw dan teori-teori pembelajaran jigsaw. Komponenkomponen yang terdapat dalam model yang dikembangkan yaitu: perencanaan, pelaksanaan, dan penilaian pembelajaran; (4) uji lapangan awal, yaitu meliputi uji lapangan berskala kecil dengan subjek penelitian yang sedikit pula, dan melakukan analisis data hasil penelitian.

Berdasarkan pada tahapan penelitian dan pengembangan tersebut, selanjutnya langkah-langkah penelitian dan pengembangan pada penelitian ini dapat digambarkan sebagai berikut:

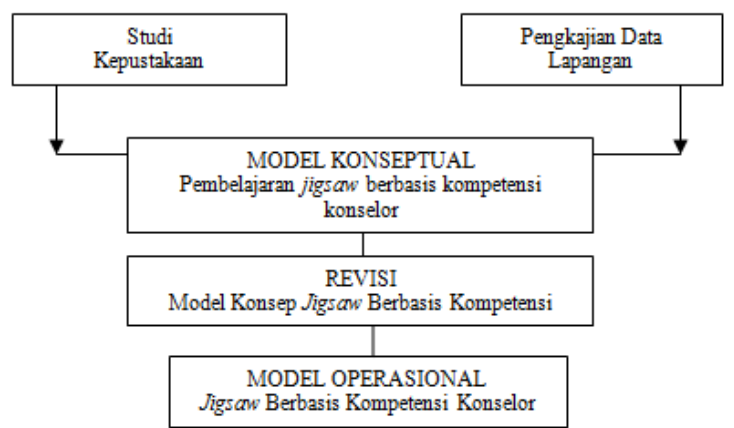

Gambar 1Prosedur Penelitian dan Pengembangan Pembelajaran Jigsaw berbasis Kompetensi Konselor

\section{Ruang Lingkup Penelitian}

Pada penelitian ini yang menjadi responden adalah mahasiswa program studi bimbingan dan konseling. Mahasiswa yang terlibat dalam penelitian ini adalah peserta didik semester I (satu) yang terfokus menggambil mata kuliah Dasar-Dasar Bimbingan dan Konseling. Jumlah keseluruhan responden yang terlibat berjumlah 80 orang. 
Dengan rincian sebagai berikut: kelas A pagi (26 orang), kelas B pagi (25 0rang) dan kelas A sore (27 orang) dan 2 mahasiswa yang berasal dari semester 7. Subjek penelitian ini terdiri atas tiga macam, yaitu subjek penelitian pada kegiatan penelitian eksploratif, pada validasi ahli, dan pada penelitian eksperimen. Subjek penelitian eksploratif adalah dosen pengajar dan mahasiswa yang mengikuti matakuliah Dasar-dasar Bimbingan dan Konseling di prodi BK IKIP PGRI Pontianak. Subjek validasi ahli adalah dosen yang memiliki kompetensi di bidang pengembangan kurikulum, mata kuliah Dasar-dasar Bimbingan dan Konseling. Subjek uji coba model adalah mahasiswa yang mengikuti mata kuliah Dasar-dasar BK di prodi BK semester 1 (satu). Adapun kajian variabel penelitian merujuk pada pembelajaran jigsaw sebagai upaya pencapaian tujuan belajar dengan cara bekerja sama meliputi perencanaan pembelajaran, pelaksanaan pembelajaran, dan penilaian pembelajaran. Sedangkan kompetensi konselor sebagai variabel kedua dalam penelitian ini dimaksudkan sebagai kemampuan yang dimiliki oleh mahasiswa program studi BK setelah mengalami pembelajaran mampu secara mumpuni mentransfer nilai dan ilmu yang diperolehnya. Variabel hasil belajar meliputi tiga indikator yaitu kognitif, afektif dan psikomotorik

\section{Instrumen dan Teknik Pengumpulan Data}

Instrumen yang digunakan untuk mengukur karakteristik pembelajaran jigsaw berbasis kompetensi konselor adalah angket yang dirumuskan oleh peneliti sendiri dalam bentuk skala penilaian. Beberapa sub-variabel yang tercakup di dalam variabel pembelajaran jigsaw berbasis kompetensi konselor adalah: perencanaan pembelajaran, pelaksanaan pembelajaran, dan penilaian pembelajaran dengan point indikator pencapaian kompetensi meliputi (1) memahami secara mendalam konseli yang dilayani, (2) menguasai landasan dan kerangka teoretik bimbingan dan konseling, (3) menyelenggarakan pelayanan bimbingan dan konseling yang memandirikan, dan (4) mengembangkan pribadi dan profesionalitas konselor secara berkelanjutan.Perumusan butir-butir pertanyaan dalam angket didasarkan pada indikator-indikator yang menunjukkan gejala empirik yang tercakup di dalam masing-masing variabel. Instrumen ini digunakan untuk memperoleh data tentang jigsawdalam studi eksplorasi.

\section{Analisa Data}

Prosedur yang digunakan dalam menerapkan analisis deskriptif adalah sebagai berikut: (1) verifikasi data, yaitu peneliti melakukan kaji ulang terhadap data yang terkumpul berkenaan dengan pencapaian hasil belajar mahasiswa dan proses pembelajaran yang dilakukan oleh mahasiswa dalam mata kuliah dasar-dasar bimbingan dan konseling untuk dipilah-pilah dengan maksud untuk mengetahui kelengkapan dan ketepatan dalam pengisian instrumen penelitian. Data yang dianggap kurang lengkap dan tidak dapat dianalisis kemudian disortir; (2) koding data, yaitu peneliti melakukan pengkodean atas data penelitian untuk memudahkan proses entridata ke dalam komputer, yakni berupa hasil entri data hasil pembelajaran tiap mahasiswa yang mengikuti perkuliahan selama satu semester dengan membandingkanya dengan pemerolehan hasil akhir belajar mahasiswa setelah pembelajaran jigsaw berbasis kompetensi konsleor dilaksanakan; (3) entri data, yaitu peneliti memasukkan data ke dalam komputer yang sebelumnya telah ditetapkan kode pada masing-masing jawaban responden; dan (4) analisis data, yaitu menerapkan rumus analisis statistika deskriptif yang terdapat dalam program SPSS release 20.0 untuk mengetahui frekuensi dan persentase masing-masing jawaban responden. Sesudah print out data diperoleh, data selanjutnya dideskripsikan sesuai dengan permasalahan dan tujuan yang ingin dicapai dalam penelitian ini. Selanjutnya, pengelolaan dan analisis data inferensial digunakan program paket statistika Statistical Package for Social Sciences (SPSS) release 20.0.

\section{HASIL DAN PEMBAHASAN}

\section{A. Hasil Penelitian}

Berdasarkan hasil observasi pembelajaran yang dilaksanakan pada mahasiswa semester 1 tahun ajaran 2015/2016 di Program Studi Bimbingan dan Konseling diperoleh data penelitian berupa: (1) partisipasi mahasiswa dalam mengikuti perkuliahan cenderung pasif yang ditunjukkan dengan kurangnya antusiasme mahasiswa terhadap diskusi kelas yang disampaikan oleh rekan sejawat bahkan oleh dosen pengampu mata kuliah. (2) mahasiswa masih belum menguasai materi informasi yang diberikan sehingga pemahaman mahasiswa masih minim sehingga materi baru yang disampaikan juga tidak dapat dipahami sepenuhnya oleh mahasiswa. (3) dalam pelaksanaan diskusi kelompok tanpa teknik jigsaw, keaktifan serta penguasaan materi oleh mahasiswa masih belum merata, sehingga mahasiswa yang aktif masih beberapa persen dari jumlah keseluruhan dan mahasiswa lain tidak memiliki motivasi untuk dapat ikut aktif dalam perkuliahan.(4) Metode pembelajaran yang digunakan cenderung teoritis dan aspek kognitif masih mewarnai pembelajaran. Sehingga DasarDasar BK belum dilaksanakan sesuai kompetensi yang diharapkan. Kehadiran dosen di kelas masih belum maksimal dalam memberikan pemahaman terkait pengetahuan Dasar-Dasar BK.Kompetensi dalam mata kuliah Dasar-Dasar BK merupakan tuntutan kebutuhan calon guru BK dalam memahami konsep dan ruang lingkup kerja dalam memberikan layanan kepada peserta didik.

Pembelajaran jigsaw berbasis kompetensi konselor merupakan proses pengembangan model pembelajaran Dasar-Dasar BK dengan pendekatan konstruktivistik metode jigsaw dilakukan melalui dua tahapan, yakni tahap prapengembangan model dan tahap pengembangan.Berdasarkan studi pendahuluan tersebut dapat diperoleh informasi tentang analisis kebutuhan sebagai dasar pengembangan model. Hasil analisis kebutuhan responden yang menggambil mata kuliah Dasar-Dasar BK menunjukkan bahwa: 
1) Hasil pembelajaran masih berorientasi aspek kognitif, belum mengoptimalkan aspek kompetensi konselor yang mutlak dimiliki oleh mahasiswa calon guru bimbingan dan konseling.

2) Mahasiswa belum dapat mengembangkan materi pembelajaran selain yang diberikan oleh dosen.

3) Mahasiswa belum terbiasa belajar mandiri di kelas tanpa kehadiran dosen, sehingga ketergantungan dengan dosen masih tinggi.

4) Penggunaan metode ceramah masih mendominasi dalam kegiatan pembelajaran. LCD di kelas belum digunakan.

5) Mahasiswa merasakan tidak memperoleh umpan balik hasil belajar yang telah dilakukan.

6) Mahasiswa masih cenderung memperoleh materi yang teoretis dan kurang praktis cenderung hafalan.

7) Mahasiswa merasa kesulitan mengemukakan gagasannya di depan kelas

8) Mahasiswa kurang melihat mata rantai antara topik pembelajaran yang satu dengan lainnya.

Maka dari hal tersebut, maka disusunlah rancangan pembelajaran jigsaw berbasis kompetensi konselor, yaitu sebagai berikut:

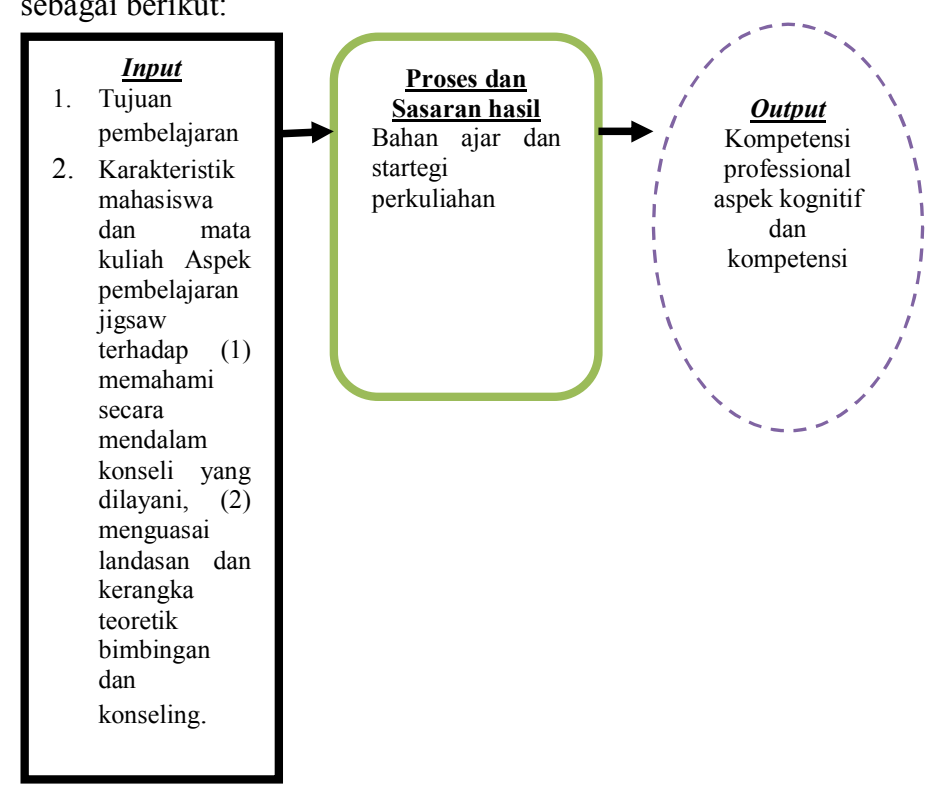

Gambar 2. Bagan Model Awal

Selain itu kompetensi konselor yang diselipkan dijadikan upaya bagi mahasiswa melatih kompetensikompetensi yang harus dimiliki berkaitan dengan kemampuan (a) mengenal secara mendalam konseli yang hendak dilayani, (b) menguasai khasanah teoretik konteks, asas, dan prosedur serta sarana yang digunakan dalam penyelenggaraan pelayanan bimbingan dan konseling. 
TABEL I

RANGKUMAN HASIL PENGEMBANGAN PEMBELAJARAN JIGSAW BERBASIS KOMPETENSI KONSELOR

\begin{tabular}{|c|c|c|c|c|}
\hline \multirow[t]{2}{*}{ No } & \multirow[t]{2}{*}{ Tahapan } & \multicolumn{2}{|c|}{ Kegiatan } & \multirow[t]{2}{*}{ Tujuan } \\
\hline & & Model Awal & Model Hipotetik & \\
\hline \multirow[t]{2}{*}{1} & \multicolumn{4}{|c|}{ Input } \\
\hline & & $\begin{array}{l}\text { Dosen : } \\
\text { a. Mempersiapkan kondisi } \\
\text { mahasiswa } \\
\text { b. Apersepsi } \\
\text { c. Menyampaikan } \\
\text { tujuan pembelajaran } \\
\text { dan memberikan } \\
\text { motivasi belajar }\end{array}$ & $\begin{array}{l}\text { Dosen: } \\
\text { a. Mempersiapkan } \\
\text { kondisi mahasiswa b. } \\
\text { Apersepsi } \\
\text { c. Menyampaikan } \\
\text { tujuan } \\
\text { pembelajaran } \\
\text { dan memberikan } \\
\text { motivasi belajar }\end{array}$ & $\begin{array}{l}\text { Membangun gagasan } \\
\text { mahasiswa agar dapat } \\
\text { melakukan aktivitas } \\
\text { belajar dengan baik. }\end{array}$ \\
\hline \multirow[t]{6}{*}{2} & \multicolumn{4}{|c|}{ Proses } \\
\hline & Situasi & $\begin{array}{l}\text { Mahasiswa: } \\
\text { a. Menerima dan } \\
\text { memahami informasi } \\
\text { tentang materi } \\
\text { konsep pokok } \\
\text { b.Melakukan interaksi } \\
\text { dengan berbagai } \\
\text { sumber belajar }\end{array}$ & $\begin{array}{l}\text { Mahasiswa: } \\
\text { a. Membentuk kelompok } \\
\text { b. Melakukan } \\
\text { penelusuran } \\
\text { berbagai sumber } \\
\text { belajar. }\end{array}$ & \\
\hline & $\begin{array}{l}\text { Membentuk } \\
\text { kelompok }\end{array}$ & $\begin{array}{l}\text { Kelompok untuk } \\
\text { belajar } \\
\text { pembahasan materi } \\
\text { klasikal dengan } \\
\text { presentase teori } \\
\text { lebih banyak, }\end{array}$ & $\begin{array}{l}\text { Membentuk } \\
\text { kelompok heterogen } \\
(8-10) \text { pemecahan } \\
\text { masalah melalui } \\
\text { topik bebas dengan } \\
\text { wahana kelompok }\end{array}$ & $\begin{array}{l}\text { Memberikan } \\
\text { kesempatan untuk } \\
\text { melakukan konstruksi } \\
\text { pengetahuan sesuai } \\
\text { dengan } \\
\text { karakteristiknya. }\end{array}$ \\
\hline & Pertanyaan & $\begin{array}{l}\text { Tidak dilakukan } \\
\text { setiap pertemuan } \\
\text { baik lisan tertulis }\end{array}$ & $\begin{array}{l}\text { Menggali gagasan } \\
\text { untuk membangun } \\
\text { pengetahuan baru } \\
\text { guna mengatasi } \\
\text { masalah dengan } \\
\text { dinamika kelompok }\end{array}$ & \\
\hline & Eksibisi & $\begin{array}{l}\text { Tidak memberikan } \\
\text { balikan hasil belajar } \\
\text { melalui akademik nilai } \\
\text { UAS tidak secara }\end{array}$ & $\begin{array}{l}\text { Memberikan balikan } \\
\text { hasil belajar yang } \\
\text { telah ditempuhnya }\end{array}$ & \\
\hline & Refleksi & $\begin{array}{l}\text { individual atau } \\
\text { kelompok } \\
\text { (Tidak Ada Refleksi di tahap } \\
\text { proses ) }\end{array}$ & $\begin{array}{l}\text { Mengembangkan } \\
\text { berfikir kritis melalui } \\
\text { wahana kelompok } \\
\text { selama proses } \\
\text { pembelajaran }\end{array}$ & \\
\hline \multirow[t]{4}{*}{3} & \multicolumn{4}{|c|}{ Output } \\
\hline & & Mahasiswa : & Mahasiswa : & Meningkatkan \\
\hline & & $\begin{array}{l}\text { Membuat laopran } \\
\text { secara tertulis . } \\
\text { - membuat power poin } \\
\text { untuk persiapan } \\
\text { presentasi }\end{array}$ & $\begin{array}{l}\text { Mengerjakan / } \\
\text { mendiskusikan } \\
\text { tugas } \\
\text { untuk memahami } \\
\text { dan menyusun } \\
\text { konsep pokok }\end{array}$ & $\begin{array}{l}\text { Melatih kompetensi } \\
\text { konselor. }\end{array}$ \\
\hline & & & $\begin{array}{l}\text { - Laporan tertulis dan } \\
\text { presentasi bentuk } \\
\text { softfile. }\end{array}$ & \\
\hline
\end{tabular}




\section{B. Pembahasan}

Pengembangan pembelajaran jigsaw berbasis kompetensi konselor, dirancang berdasarkan komponen pembelajaran yaitu input, proses, dan output. Untuk komponen input yang diperhatikan yaitu penerapan tujuan pembelajaran yang sesuai dengan metode jigsaw. Selanjutnya, mahasiswa sebagai subyek penelitian dan karakteristik mata kuliah Dasar-Dasar BK yang merupakan ciri khas prodi Bimbingan dan Konseling. Melalui pembelajaran Dasar-Dasar BK dengan metode jigsaw berbasis kompetensi konselor diharapkan dapat mengembangkan kemampuan aspek kognitif dan keterampilan melaksanakan layanan bimbingan dan konseling. Untuk komponen proses, bahan ajar yang dikembangkan adalah materi pembelajaran yang dibutuhkan sesuai kompetensi yang ingin dicapai. Strategi pembelajaran menggunakan metode jigsaw memudahkan mahasiswa dalam menguasai satu materi ajar dan bertanggung jawab untuk mampu mentransferkan pengetahuan yang telah diperolehnya kepada rekan kelompok kelas lainnya. Selain itu, mahasiswa dapat mengenali, menelusuri, mengidentifikasi, dan membedakan yang akhirnya dapat menyusun konsep tentang Dasar-dasar BK. Dibandingkan dengan metode ceramah maupun diskusi secara umum dan khusus model pembelajaran jigsaw mengutamakan kemampuan mahasiswa dalam mengeksplorasi dan menangkap pemahaman sendiri atas materi yang dipelajari. Beberapa keuntungan yang diperoleh dengan metode jigsaw berbasis kompetensi konselor ini adalah mahasiswa mendasarkan kegiatan pembelajaran sesuai dengan kompetensi konselor yang hendak dicapai dalam proses perkuliahan dasar dasar Bimbingan dan Konseling.

Komponen output, diharapkan setelah mengikuti kegiatan pembelajaran dengan metode jigsaw berbasis kompetensi konselor, mahasiswa dapat meningkatkan pengetahuan dan keterampilan melaksanakan layanan bimbingan dan konseling secara profesional.Untuk efektivitas model dapat dilihat dari respon mahasiswa. Berdasarkan respon mahasiswa sebagai subyek penelitian bahwa sebagian besar responden sangat setuju karena pembelajaran jigsaw berbasis kompetensi konselor memberi kesempatan untuk menggali informasi yang diperlukan.

\section{KESIMPULAN}

Melakukan inovasi terhadap desain model dan pengembangan bahan ajar yang lebih inovatif dan kreatif salah satunya dengan teknik jigsaw berbasis kompetensi konselor sehingga mahasiswa dapat berkembang sesuai kemampuan yang dimilikinya. Untuk dapat melakukan model ini dengan baik, maka di harapkan guru pembimbing memiliki kemampuan dalam memberikan dorongan positif. Pendekatan behavioristik yang selama ini digunakan oleh dosen lambat laun akan di tinggalkan menuju belajar mandiri secara tuntas. Mengembangkan strategi pembelajaran maka dapat melibatkan semua mahasiswa. Mengembangkan model evaluasi belajar sebaiknya tidak hanya mengukur aspek kognitif tetapi juga bentuk tes perbuatan yang dapat mengukur kinerja sesungguhnya mahasiswa dalam mengikuti proses pembelajaran.

\section{DAFTAR PUSTAKA}

[1] Wibowo, Mungin Edy, 2005. Standardisasi Profesi Konseling. Semarang: Konvensi Nasional XIV dan Kongres Nasional X ABKIN

[2] Banun, Sri Haksasi dan Heru, Mugiarso (2015). Mode Pengembangan Kompetensi Konselor Multikultural Berbasis Experient Learning Melalui Media Film Populer. Majalah Ilmiah Pawiyatan Vol: XXII, Nomor 3, Oktober 2015.

[3] Restu, Setyoningtyas. (2014). Persepsi Guru BK tentang Kompetensi Konselor.

[4] Masturoh. (2005). Pengaruh Pembelajaran Cooperatif Learning Dengan Model JigsawTerhadap Hasil Belajar Matematika. Tesis. Jakarta: FITK UIN Syarif Hidayatullah. 